\title{
Cytomegalovirus Infection Seen After Eosinophilic Granulomatosis With Polyangiitis - A Case Report
}

\section{Eosinofilik Granülomatoz Polyangiitis Sonrası Görülen Sitomegalovirus Enfeksiyonu - Olgu Sunumu}

\author{
Kezban Armağan Alptürker ${ }^{*}$, Özgül Soysal Gündüz², Nurullah Akkoç² \\ ${ }^{1}$ Department of Physical Medicine and Rehabilitation Division of Rheumatology, Celal Bayar University School of \\ Medicine, Manisa, Turkey \\ ${ }^{2}$ Department of Internal Medicine, Division of Rheumatology, Celal Bayar University School of Medicine, Manisa, \\ Turkey \\ e-mail: kezban887@gmail.com, soysalozgul@gmail.com, nurullah.akkoc@gmail.com \\ ORCID: 0000-0001-7380-6097 \\ ORCID: 0000-0002-8149-9311 \\ ORCID: 0000-0002-3718-171X \\ *Sorumlu yazar/ Corresponding Author: Kezban Armağan Alptürker \\ Gönderim Tarihi / Received: 29.03.2021 \\ Kabul Tarihi / Accepted: 07.05.2021 \\ DOI: $10.34087 /$ cbusbed.905088
}

\begin{abstract}
$\ddot{O} z$
Churg-Strauss Sendromu olarak da bilinen eozinofilik granülomatozis polianjit (EGPA), ekstravasküler granülomlar ve eozinofili ile karakterize, küçük ve orta damarları tutan sistemik nekrotizan bir vaskülittir. Vaskülitin tedavisi esas olarak kortikosteroidlerle olur ve şiddetli hastalık tablosunda diğer immünosüpresif ajanlar eklenebilir. Burada, EGPA tanısı alan 57 yaşında bir erkek hastayı ve tedavi sonrası görülen hepatit nedeni olarak firsatçı bir enfeksiyon gelişen olguyu sunmak istedik Cytomegalovirus (CMV), sık görülen firsatçı enfeksiyon nedenidir ve bağışıklığı baskılanmış hastalarda çeşitli semptomlara ve hatta ölüme neden olabilir. Nadiren akut hepatite de neden olmaktadır Fırsatçı enfeksiyonlar, vaskülite neden olabildiği gibi immünsüprese tedaviler sonrası da reaktive olabilir.
\end{abstract}

Anahtar Kelimeler: Eozinofilik granülomatöz polianjitis (EGPA), Cytomegalovirus (CMV), akut hepatit.

\section{Abstract}

Eosinophilic granulomatosis with polyangiitis (EGPA) also known as Churg- Strauss syndrome is a systemic smalland medium-vessel necrotizing vasculitis, characterized by extravascular granulomas, and eosinophilia. Treatment is primarily with corticosteroids and, for severe disease, addition of other immunosuppressive agents. Here, Here, we want to present a 57-year-old male patient who was diagnosed with EGPA and developed an opportunistic infection as the cause of hepatitis after treatment. Cytomegalovirus (CMV) is a common cause of opportunistic infection and can cause various symptoms and even mortality in immunocompromized patients. It is rarely cause of acute hepatitis. Opportunistic infections may cause vasculitis as well as reactivate after immunosuppressed treatments.

Key words: Eosinophilic granulomatosis with polyangiitis (EGPA), Cytomegalovirus, acute hepatitis.

\section{Introduction}

Churg-Strauss syndrome (CSS), which is currently called the Eosinophilic granulomatosis with polyangiitis (EGPA), is a vasculitis of medium to small sized vessels, that affects many organs including cardiac, pulmonary, renal, nervous, and vascular systems. EGPA is characterized by chronic rhinosinusitis, asthma and marked peripheral blood eosinophilia. EGPA may be ANCA-positive or ANCA-negative, although there is no disease criterion [1].
The most commonly affected organs are the lungs. Asthma is the most common manifestation in presentation with more than 90 percent of patients and mononeuritis multiplex is the second most common [2]. Here we report a case of a 57- year-old man with EGPA. While our patient was being follow-up after treatment of EGPA, his liver function tests were elevated. Cytomegalovirus (CMV) infection an opportunistic infection and is often symptomatic in immunocompromized patients. In some cases, the viral 
agent has been thought to play a role in the pathogenesis of vasculitis[3].

Here we report a case of EGPA and CMV may also play an etiological role of some vasculitis, a rare cause of acute hepatitis, after treatment with high dose glucocorticoids and cyclophosphamide

\section{Case Report}

A 57-year-old man, ex-smoker, with general fatigue, fever, sore throat, wandering joint pain for about 1 month. He was admitted to Celal Bayar University Hospital because of weakness and numbness in the first 3 fingers of the right hand and numbness on the outer surface of the left leg for 3 days. The patient who suffered from anorexia had lost weight of $15 \mathrm{~kg}$ in the last month. $\mathrm{He}$ was diagnosed with Still's disease in the external center and started on $24 \mathrm{mg}$ corticosteroid and his complaints have partially regressed.

As the patient had a lung nodule detected 15 years ago and asthma-like symptoms started 3 years ago, examinations were performed. On initial examination, pulse rate was 105 / minutes, respiratory rate 22 /minutes and blood pressure was $130 / 80 \mathrm{~mm} \mathrm{Hg}$. Respiratory system examination revealed common rhonchi associated with asthma. Nervous system examination revealed asymmetrical distal muscle weakness with sensory loss. Muscle strength examination (muscle strength grading on a 0 to 5 scale) at right arm abductor / adductor $5 / 5$, right elbow flexion / extansion $4 / 5$, first 3 fingers muscle of right hand strength $3 / 5$ and dorsiflexion of the left foot $4 / 5$. Deep tendon reflexes were bilateral hypoactive, no pathological reflex was detected. Other system examination was normal.

Laboratory investigations found the following values: hemoglobin $13.3 \mathrm{~g} / \mathrm{dl}$, total Leukocyte count 21,22 cells/mm3, (Neutrophils 60,5\%, Lymphocytes 6,7\%, Monocytes 3,6\% and Eosinophils 28.8\%), platelet count was 593,000 per cubic millimeter. Our patient's erythrocyte sedimentation rate (ESR) was $44 \mathrm{~mm} / \mathrm{h} \mathrm{C}$ reactive protein was (CRP) $: 8,1 \mathrm{mg} / \mathrm{dL}$. Liver function test were moderate increased; alanine transaminase (ALT):113 U/L (0-50 U/L), aspartate transaminase (AST) :42 U/L (0-50 U/L), lactate dehydrogenase (LDH):382 U/L (0-248 U/L), gamma-glutamyl transpeptidase (GGT): $213 \mathrm{U} / \mathrm{L}(0-55)$ and renal function tests and electrolytes were within normal limits.Results of a urinalysis were protein:0.5g $(\mathrm{g} / \mathrm{dL})(+1)$ and sediment (at every large magnification field erythrocyte:25 leukocyte:2) in microscopic examination. Chest $\mathrm{X}$ ray had been performed and showed LAP in the pretracheal region and poorly defined nodules of focal consolidation in the right lower lobes (Figure 1). Chest computed tomography (CT) demonstrates diffuse areas of ground glass opacities and millimetric pulmonary nodüle in the left and right lung (Figure 2). positron emission tomography (PET) was negative.

Test for antinuclear antibody (ANA) and neutrophil cytoplasmic antibody (cANCA) were negative, p-ANCA (perinuclear antineutrophil cytoplasmic antibody) was detected positive.

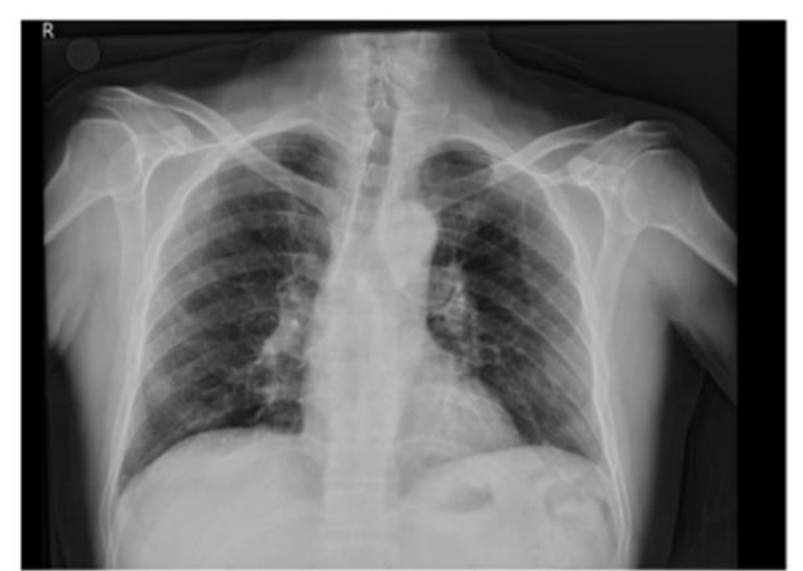

Figure 1. Chest $X$ ray showed LAP in the paratracheal region and poorly defined nodules of focal consolidation in the right lower lobes.

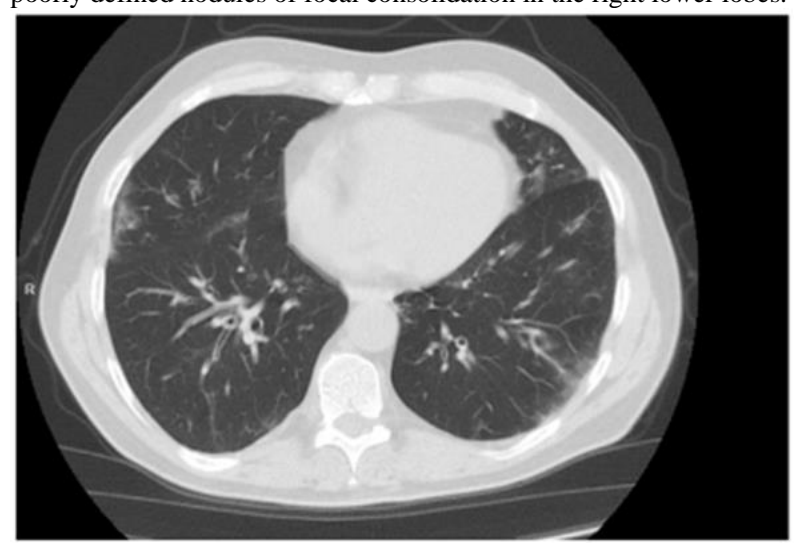

Figure 2. Chest computed tomography. Axial image demonstrates diffuse areas of ground glass opacities and millimetric pulmonary nodule in the left and right lung.

Serum complement levels (C3 and C4) in the outer center was high Serum IgE level was:442 (normally 0-87 $\mathrm{IU} / \mathrm{mL}$ ). Chest X-ray was taken and was similar to the previous image. Abdominal ultrasonography was performed and liver size was slightly enlarged.

Electromyography (EMG) was performed and the electrophysiological findings were reported as consistent with asymmetric sensorimotor polyneuropathy. Studies were suggestive of mononeuritis multiplex.

The patient was consulted with cardiology and Echocardiography (ECHO) was performed, no significant pathology was observed.

On investigation he had increased peripheral blood eosinophilia, pulmonary function test showed reversible airway obstruction,nerve conduction studies revealed mononeuritis multiplex, elevation of IgE and p-ANCA also support this diagnosis of EGPA. The patient's previous $24 \mathrm{mg}$ corticosteroids treatment was changed to corticosteroids $(1 \mathrm{mg} / \mathrm{kg} /$ day) to induce remission . At the first week of the treatment, a dramatic decrease in blood eosinophil count was observed. Because of refractory EGPA, intravenous bolus of cyclophosphamide was added with premedication according to protocol and there were no complications. Liver enzymes were elevated ( ALT: 215 AST:22 GGT:270 ) on the 5th day of cyclophosphamide treatment during hospitalization. Hepatitis and CMV antibodies were requested with the recommendation of 
gastroenterology. Hepatitis markers were negative. CMV Ig-G was positive (Positive: (53) AU / mL) and Ig-M gray zone GZ:0.87 (GZ 0.7-0.9) CMV Ig-M test was repeated and positive result. Polymerase chain reaction for monitoring of cytomegalovirus (CMV) infection was postive. According to these findings, patient was diagnosed as acute hepatitis due to the CMV infection. $\mathrm{He}$ was iniated $2 \mathrm{x} 5 \mathrm{mg} / \mathrm{kg}$ ganciclovir with the recommendation of infectious diseases. There was a decrease in enzymes (ALT: 61 AST:22 GGT:129) one week after antiviral treatment. Antiviral treatment (Ganciclovir $5 \mathrm{mg} / \mathrm{kg}$ IV every 12 hours induction therapy ) was continued for 21 days. Result of CMV PCR was $<69 \mathrm{IU} / \mathrm{mL}$ (normal range 137-9100000 1u/mL) at one month.

\section{Discussion}

EGPA has a relatively low incidence, usually occurring in patients with asthma and allergic rhinitis. The vasculitis phase usually develops within 3 years of the onset of asthma [4]. The mean age at diagnosis of EGPA is 40 years and both sexes are affected equally [5]. Peripheral blood eosinophilia (usually 5000 to 9000 eosinophils/microL) is the most characteristic finding. At the first visit of our patient eosinophil count was 6.11 $(10 \wedge 3 / \mu \mathrm{L})$,It was much higher than the diagnostic standard (Eosinophils 28.8 percent greater than 10 percent of the total leukocyte count). Patients with strongly suspected or known EGPA, additional tests are performed to assess the extent of other than eosinophilia [6]. Our patient had positive p-ANCA although not included in the diagnostic criteria that also support this diagnosis. In a series of 157 consecutive patients with EGPA, 49 (31 percent) were ANCA positive . ANCApositivity was associated with weight loss, myalgias, arthralgias, biopsy-proven vasculitis, glomerulonephritis on biopsy, hematuria, leukocytoclastic capillaritis and/or eosinophilic infiltration of the arterial wall on biopsy and other renal disease [7]. Our patient had myalgias, migratory polyarthralgias and weight loss. These symptoms occur less frequently but may affect 40 to 50 percent of patients in the vasculitic phase of the disease [8].

Chest radiograph was obtained at first visit also. The patient's previous history of asthma also supported the diagnosis. When the vasculitic phase begins, asthma severity and exacerbation may increase [9]. But asthma in our patient was more moderate, weight loss and neuropathy were more prominent.

A peripheral neuropathy, Mononeuritis multiplex that is most frequent form, is seen in up to 75 percent of patients with EGPA [10]. Our patients neuropathy was compatible with mononeuritis multiplex, predominantly median nerve involvement. Thenar atrophy was seen in right hand.

The American College of Rheumatology (ACR) has established six criteria for the classification of EGPA in a patient with documented vasculitis. The presence of four or more of these criteria had a sensitivity of 85 percent and a specificity of 99.7 percent for EGPA, [11].
Our patient fulfilled the criteria of the ACR and met the following definition for EGPA proposed by the Chapel Hill Consensus Conference : (a) Asthma (a history of wheezing or the finding of diffuse high pitched wheezes on expiration),(b) Greater than 10 percent eosinophils on the differential leukocyte count, Mononeuropathy (including multiplex) or polyneuropathy, (c) Migratory or transient pulmonary opacities detected radiographically (d) neuropathy, (e) Paranasal sinus abnormality, and (f) Biopsy containing a blood vessel showing the accumulation of eosinophils in extravascular areas.

The French Vasculitis Study Group has recently revised 5 prognostic factors, the so-called 5-factor score (FFS). (a) Age $>65$, (b) Cardiac insufficiency, (c) Gastrointestinal involvement, (d) Renal insufficiency (stabilized peak plasma creatinine concentration $>1.7$ $\mathrm{mg} / \mathrm{dL}$ [150 micromol/L]), (e) Absence of ear, nose, and throat (ENT) manifestations (presence is associated with a better prognosis). These scoring systems are used to guide initial therapy and also been correlated with prognosis [12]. Our patient had none of these factors. But our patient had acute mononeuritis multiplex and positive p-ANCA. In this situation, some experts would also use cyclophosphamide with an FFS of 0 and a positive ANCA, as these patients tend to develop renal involvement and biopsy findings vasculitis [13]. Initial treatment uses oral corticosteroids are recommended for therapy for EGPA. We treated our resistant patient with prednisone at a dose of $1 \mathrm{mg} / \mathrm{kg}$ per day and also added iv cyclophosphamide.Our patient responded quickly to immunosuppressive therapy.

Liver function tests elevation was seen after 5th day of hospitalization. As a result of examinations we found positive anti-CMV-IgM and anti-CMV-IgG serum titers (Positive $>=0.9$ ). Cytomegalovirus (CMV), a human herpes virus, is common in healthy adults and children who are often asymptomatic or only cause a mild disease, but cause serious morbidity in in the immunocompetent host [14]. There was no other symptom(like fever, sore throat, lymphadenopathy) except liver function test (especially ALT) abnormality was seen in our case related with CMV infection. ALT (liver-specific) was four times increase up to in this case. Steroid and immunsupression therapy were known to reactivate the latent virus. Reactivation and disease in immunocompromised individuals is associated with significant morbidity and mortality [15]. the occurrence of this infection was thought to be a result of the treatment, not the cause of the disease.

\section{Limitation}

The fact that it is a single case is a limitation of this study. Written informed consent was obtained from the patient for publication of this case report and accompanying images. In this study, national and international ethical rules are observed.

\section{Conclusion}

In this case, we mentioned the p-ANCA positive EGPA presenting with acut mononeuritis multiplex and weight 
loss. Elevated transaminase level following treatment were associated with CMV. Thus, screening for and identification of viral infections in immunocompromised individuals who presented with acute hepatitis reduces morbidity and mortality.

\section{References}

1. Pagnoux, C, Guilpain, P, Guillevin, L, Churg-Strauss syndrome, Current Opinion in Rheumatology, 2007, 19, 1, 25-32.

2. Comarmond, C, Pagnoux, C, Khellaf, M, Cordier, J.F, Hamidou, M, Viallard, J.F et al., Eosinophilic granulomatosis with polyangiitis (Churg-Strauss): clinical characteristics and long-term followup of the 383 patients enrolled in the French Vasculitis Study Group cohort, Arthritis \& Rheumatism, 2013, 65, 1, 270-281.

3. Doherty, M, Bradfield, J.W, Polyarteritis nodosa associated with acute cytomegalovirus infection, Annals of the Rheumatic Diseases, 1981, 40, 4, 419-421.

4. Abril, A, Calamia, K.T, Cohen, M.D, The Churg-Strauss syndrome (allergic granulomatous angiitis): review and update, Seminars in Arthritis Rheumatology, 2003, 33, 106-14.

5. Conron, M, Beynon, H.L, Huw, L.C, Churg-strauss syndrome, Thorax, 2000, 55, 10, 870-877.

6. Noth, I, Strek, M.E, Leff, A.R, Churg-Strauss syndrome, The Lancet, 2003, 361, 587-594.

7. Cottin, V, Bel, E, Bottero, P, Dalhoff, K, Humbert, M, Lazor, R, et al., Revisiting the systemic vasculitis in eosinophilic granulomatosis with polyangiitis (Churg-Strauss): A study of 157 patients by the Groupe d'Etudes et de Recherche sur les Maladies Orphelines Pulmonaires and the European Respiratory Society Taskforce on eosinophilic granulomatosis with polyangiitis (Churg-Strauss). Autoimmunity Reviews, 2017, 16, 1, 1-9.

8. Guillevin, L, Cohen, P, Gayraud, M, Lhote, F, Jarrousse, B, Casassus $\mathrm{P}$, Churg-Strauss syndrome, Clinical study and long-term follow-up of 96 patients, Medicine (Baltimore), 1999, 78, 1, 26-37.

9. Wechsler, M.E, Garpestad, E, Flier, S.R, Kocher, O, Weiland, D.A, Polito, A.J, et al., Pulmonary infiltrates, eosinophilia, and cardiomyopathy following corticosteroid withdrawal in patients with asthma receiving zafirlukast, JAMA, 1998, 279, 6, 455-457.

10. Della Rossa, A, Baldini, C, Tavoni, A, Tognetti, A, Neglia, D, Sambuceti, G et al., Churg-Strauss syndrome: clinical and serological features of 19 patients from a single Italian centre, Rheumatology, 2002, 41, 11, 1286-1294.

11. Masi, A.T, Hunder, G.G, Lie, J.T, Michel, B.A, Bloch, D.A, Arend, W.P, et al, The American College of Rheumatology 1990 criteria for the classification of Churg-Strauss syndrome (allergic granulomatosis and angiitis), Arthritis \& Rheumatism, 1990, 33, 8, 1094-1100

12. Guillevin, L, Pagnoux, C, Seror, R, Mahr, A, Mouthon, L, Le Toumelin, P, et al., The Five-Factor Score revisited: assessment of prognoses of systemic necrotizing vasculitides based on the French Vasculitis Study Group (FVSG) cohort, Medicine, 2011, 90, 1, 1927.

13. Sablé-Fourtassou, R, Cohen, P, Mahr, A, Pagnoux, C, Mouthon, L Jayne, D, et al., Antineutrophil cytoplasmic antibodies and the Churg-Strauss syndrome, Annals of Internal Medicine, 2005, 143, 9, 632-638.

14. Staras, S.A, Dollard, S.C, Radford, K.W, Flanders, W.D, Pass, R.F, Cannon, M.J, Seroprevalence of cytomegalovirus infection in the United States, 1988-1994, Clinical Infectious Diseases, 2006, 43, 9, 1143-1151.

15. Nolan, N. Halai, U. A, Regunath, H, Smith, L, Rojas-Moreno, C, Salzer, W, Primary cytomegalovirus infection in immunocompetent adults in the United States-A case series, ID Cases, 2017, 10, 123126. http://edergi.cbu.edu.tr/ojs/index.php/cbusbed isimli yazarın CBU-SBED başlıklı eseri bu Creative Commons Alıntı-Gayriticari4.0 Uluslararası Lisansı ile lisanslanmıştır. 